\title{
AQUATIC PLANTS OF CROATIA: DATA DERIVED FROM THE ZA HERBARIUM COLLECTION
}

\section{Antonija Zeko ${ }^{1}$, Vedran Šegota ${ }^{2 *}$, Tihana Vilović ${ }^{3}$, Nikola Koletić ${ }^{4}$ \& Antun Alegro ${ }^{4}$}

\author{
${ }^{1}$ Independent Researcher, Zagreb, Croatia
}

${ }^{2} \mathrm{ZA} \& \mathrm{ZAHO}$ herbarium collections, Division of Botany, Department of Biology, Faculty of Science, University of Zagreb, Marulićev trg 20/II, 10000 Zagreb, Croatia

${ }^{3}$ Department of Pharmaceutical Botany, Faculty of Pharmacy and Biochemistry, University of Zagreb, Schrottova 39, 10000 Zagreb, Croatia

${ }^{4}$ Division of Botany, Department of Biology, Faculty of Science, University of Zagreb, Marulićev trg 20/II, 10000 Zagreb, Croatia

Zeko, A., Šegota, V., Vilović, T., Koletić, N. \& Alegro, A.: Aquatic plants of Croatia: Data derived from the ZA herbarium collection. Nat. Croat., Vol. 29, No. 2, 205-216, 2020, Zagreb.

As many as 963 herbarium sheets featuring 76 aquatic plant taxa from the ZA collection were digitised and published online through the Virtual Herbarium. Aquatic plants have been collected over a period of 176 years, with three peaks (second decade of the $20^{\text {th }}$ century, in the 1940s and 1950s, and in the current decade). Most of the specimens were collected in Croatia and a smaller number in neighbouring and geographically close countries. The importance of the collection is expressed through the specimens of many rare and threatened species, because it represents the only evidence of their presence in Croatia (the regionally extinct Caldessia parnassifolia, as well as Luronium natans, Callitriche platycarpa, C. truncata, C. hermaphroditica, Potamogeton alpinus, P. compressus, P. polygonifolius, Nuphar $\times$ spenneriana and Sparganium minimum). The collection in ZA is a valuable source of data about the historical and recent distribution of aquatic plants that constitute a foundation for the estimation of distribution changes, threat assessment and conservation policies.

Key words: aquatic macrophytes, digitisation, Flora Croatica Database, virtual herbarium

Zeko, A., Šegota, V., Vilović, T., Koletić, N. \& Alegro, A.: Vodeno bilje Hrvatske: Podaci proizašli iz herbarijske zbirke ZA. Nat. Croat., Vol. 29, No. 2, 205-216, 2020, Zagreb.

Digitalizirana su 963 herbarijska lista 76 vodenih biljnih svojti iz zbirke ZA, te je omogućen javni pristup ovom materijalu putem online portala Virtualnog herbarija. Vodeno bilje sakupljano je u razdoblju od 176 godina, s tri maksimuma (u drugom desetljeću 20. stoljeća, tijekom 1940-ih i 1950-ih, te tijekom recentnog desetljeća). Većina biljaka je sakupljena na području Hrvatske, a manji dio u susjednim i zemljopisno bliskim državama. Važnost zbirke očituje se u značajnom broju rijetkih i ugroženih vrsta, za koje je zbirka jedini dokaz njihovog postojanja u Hrvatskoj (regionalno izumrla Caldessia parnassifolia, zatim Luronium natans, Callitriche platycarpa, C. truncata, C. hermaphroditica, Potamogeton alpinus, P. compressus, P. polygonifolius, Nuphar $\times$ spenneriana i Sparganium minimum). Zbirka vodenog bilja u ZA vrijedan je izvor podataka o povijesnoj i recentnoj rasprostranjenosti vrsta, što je temelj za procjenu promjene areala vrsta, procjenu ugroženosti te njihovu zaštitu.

Ključne riječi: vodeni makrofiti, digitalizacija, Flora Croatica Database, virtualni herbarij 


\section{INTRODUCTION}

The almost half a billion herbarium specimens hosted by herbaria worldwide (THIERs, 2020) have played a central role in plant sciences and constitute the cornerstone for systematics and taxonomy (Henning et al., 2018). This role is further strengthened with the ongoing digitisation and growing online availability of collections from all over the globe. Consequently, during the last decade, herbarium specimens and in particular their metadata became sources for ecological and distributional data of exceptional value and allowed studies on a global scale (Henning et al. 2018). Moreover, herbarium data allow the reconstruction of the evolution of taxa distribution area through time (e.g. Damerval et al., 2018). Herbarium specimens are true treasures, not only for curious visitors, but also for plant molecular systematics. For extinct, rare or geographically restricted species, herbarium collections represent an invaluable source of DNA for generating a phylogenetical framework (WANG, 2018). Recently, geometric morphometric methods started to use herbarium specimens, which are still being massively overlooked as far as these methods are concerned (CHEN et al., 2018). Since the world's herbaria contain samples spanning nearly 400 years (Soltis, 2017), the specimens can be thought of as a direct record of species' range and occurrences, their phenotypic variation and diseases, as well as time series of the phenological, demographic, and evolutionary changes and responses of populations to climatic variation, anthropogenic activity, and other biotic effects (LISTER, 2011). In addition, in recent years a few additional approaches using herbaria have emerged, such as studies on invasions, habitat change and pollution (LANG et al., 2019).

Aquatic plants are a taxonomically diverse group of plants, defined by their specific ecological adaptations to be able to thrive in running or standing waters. Therefore, among other functions, they have been put to considerable use as indicators in water quality assessments. During the $20^{\text {th }}$ century, no comprehensive study of aquatic plants, their distribution and ecology was conducted across the Croatian territory, resulting in unevenly and deficient distributional data of this group in Croatia. In order to improve that situation, during the last decade many Croatian watercourses and stagnant waters have been intensively explored with respect to aquatic plants and their vegetation, mostly within the Project of Water Bodies Surveillance based on the European Water Framework Directive (European CoMmunity, 2000), generating a number of new herbarium specimens for the oldest and largest Croatian herbarium collection Herbarium Croaticum (ZA). Although many new species have been discovered and the distribution and ecological patterns have been clarified within this project, the majority of these data have not yet been published. While discoveries of macro-algae (AlEGro et al., 2016; Koletić et al., 2017, 2018, 2019, 2020), aquatic bryophytes (Alegro et al., 2019; Rimac et al., 2019; ŠEGOTA et al., 2019a) and invasive aquatic plants (Rimac et al., 2018) have been readily published, data on general aquatic vascular flora (Š̈GOTA et al., 2019b) are still largely unprinted.

Herbaria assessments are usually made for some rare, threatened or non-native species or species groups, e.g. orchids (MolNár et al., 2012; ŠEGOTA et al., 2020) or invasive species (VILović, 2020). As for aquatic plants, comprehensive taxonomical and distributional surveys based on herbarium data were made for Potamogeton (WIEGLeB \& Kaplan, 1998), Elatine (Popiela et al., 2015; TAKács et al., 2017) and alien aquatic vascular plants (LuKÁsc et al., 2016). 
In the study reported in this paper, we conducted a survey of aquatic plants stored in the ZA collection. The main goals of our study were to (1) analyse the diversity of aquatic plants in the ZA collection, (2) digitise the collections in order to provide public availability, (3) analyse the spatial and temporal patterns within the collection and (4) broaden our knowledge on rare, data-deficient and extinct aquatic plant species in Croatia.

\section{MATERIALS AND METHODS}

Herbarium specimens of aquatic taxa from the largest and oldest Croatian herbarium collection Herbarium Croaticum (ZA), were fully restored (dusted off, translocated and mounted on new herbarium sheets), revised and digitised. Since aquatic plants are not a uniform taxonomical group, practical knowledge of aquatic flora was used to extract those taxa from the collection. The basic metadata from the herbarium labels (taxon name, locality, habitat, collecting date, collector and identifier) were stored within Flora Croatica Database (https://hirc.botanic.hr/fcd/) (NiкоLIć, 2020) and the Virtual Herbarium of ZA \& ZAHO (https://herbariumcroaticum.biol.pmf.hr) (REšETNIK \& ŠEgOTA, 2020), where ZAHO is related to the Herbarium of Ivo and Marija Horvat. Taxa names are cited in the text without the author names for simplicity, while the full names are listed in Appendix 1. The nomenclature follows NiкоLić (2020).

\section{RESULTS AND DISCUSSION}

The survey of aquatic plants in the ZA collection resulted in the discovery of 963 herbarium sheets, with as few as nine specimens (of the genus Callitriche) that were not successfully identified to species level, all due to the absence of flowers and fruits. The recorded specimens belong to 24 families and 40 genera. More than half of all specimens belong to the genus Potamogeton and the family Potamogetonaceae (29\%) and the genus Ranunculus and the family Ranunculaceae (24\%) (Figs 1 and 2). This was expected, since those genera and families contain the largest number of aquatic plant taxa in Croatia, many of them being rather common and widely distributed.

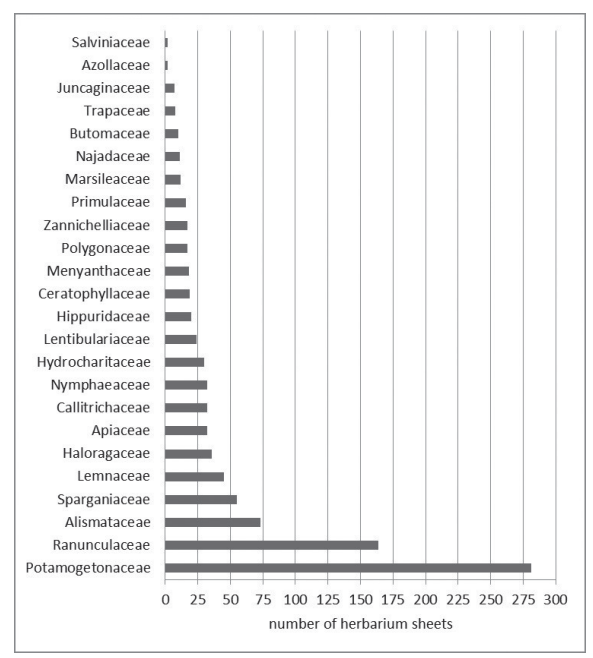

Fig. 1. The families of aquatic plants stored in ZA collection 
The analysed collection keeps as many as 74 species, one subspecies (Sparganium erectum ssp. neglectum) and one hybrid (Nuphar $\times$ spenneriana) of aquatic plants. Ranunculus trichophyllus is the species represented most abundantly in the collection (79 herbarium sheets), followed by other common species such as Potamogeton nodosus (58 sheets) and P. crispus (50 sheets) (Fig 3). On the other hand, ten species are represented with only one sheet (Caldesia parnassifolia, Damasonium polyspermum, Groenlandia densa, Luronium natans, Myriophyllum alterniflorum, Nuphar $\times$ spenneriana, Potamogeton alpinus, P. compressus, P. polygonifolius and Vallisneria spiralis). However, since all those species are extremely rare in the Croatian flora, it was only to be expected that they would be infrequent in the collection.

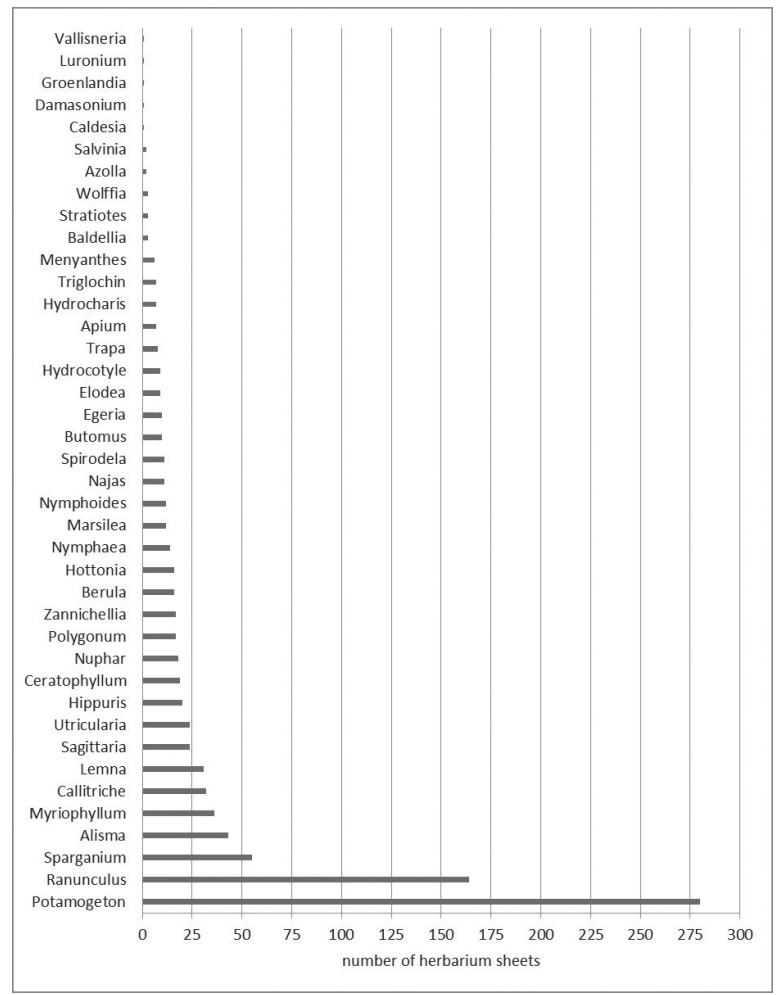

Fig. 2. The genera of aquatic plants stored in the ZA collection

Temporal coverage, at least in terms of the year of collection, was available through labels for most of the collection. The lack of temporal data for some herbarium sheets is largely due to the collections of Alfons Paulin (1853-1942) who never noted the date of collection, and partially to the collections of Hugo Erich Meyer von Klinggräff (18201902) and Josip Kalasancije Schlosser (1808-1882).

The oldest sheet analysed dates back to 1844 and bears specimens of Sagittaria sagittifolia, collected by J. K. Schlosser in Croatia, without the exact locality noted. The latest one is Damasonium polyspermum collected on 25 October 2018 by Vedran Šegota and Vladimir Hršak in Krka National Park. Similar studies of the ZA collection conducted previously revealed that the oldest invasive plant specimen was collected in 1851 (VILović et al., 2020) and the oldest orchid specimen in 1883 (ŠEgota et al., 2019c). It has 


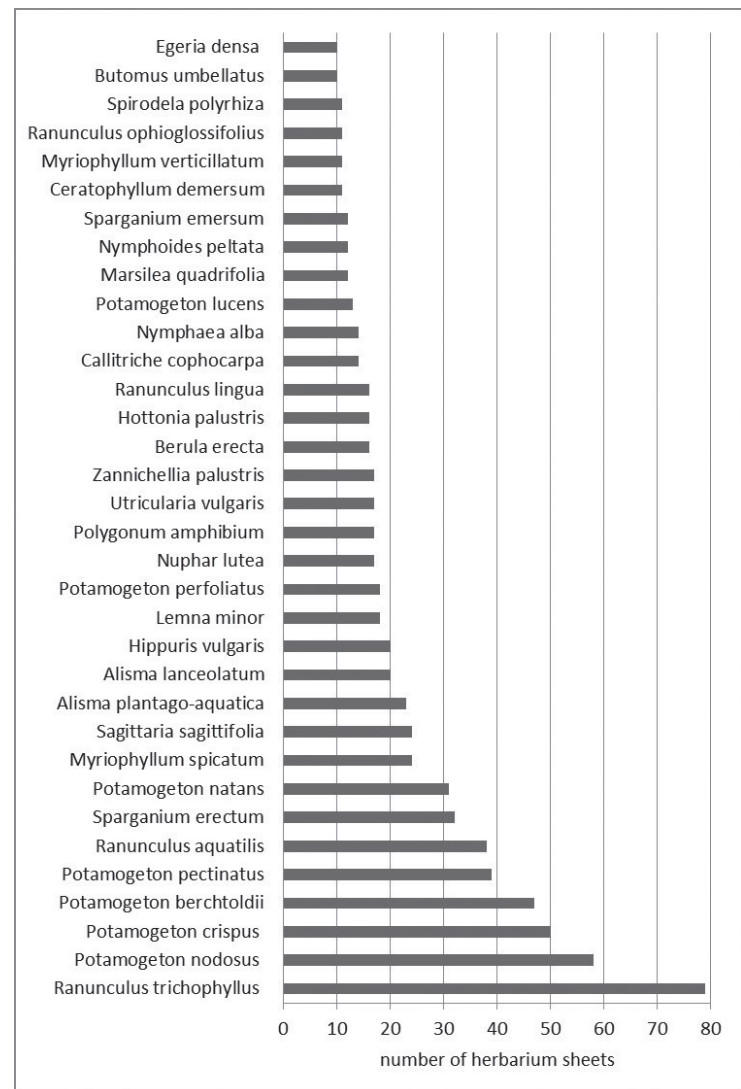

Fig. 3. The most frequently collected aquatic plant taxa in the ZA collection (only taxa with ten and more specimens shown)

been calculated that the average age of aquatic plants in ZA is 74 years, with the median year falling in 1946.

In nearly $97 \%$ of the herbarium sheets we were able to trace the time of collections - in the majority of cases, the collectors noted the exact date of collection (76.3\%), in far fewer cases only the month (6.5\%) or the year of collection (2.7\%). Finally, for the $11.3 \%$ of sheets without any temporal data, we were able to determine the century in which the specimens were collected, based on the life-span of each collector (Fig. 4).

During the 176 years in which the collection was assembled, there were considerable fluctuations in the intensity with which collecting and storing were conducted (Fig 5). There was a peak in collecting in the second decade of the $20^{\text {th }}$ century, mostly owing to efforts of Ljudevit Rossi. The second peak (in the 1940s and 1950s) can be attributed to the work of Professor Radovan Domac and Professor Ljerka Marković (her maiden name of Gospodarić is often found on the labels). However, the most fruitful collection period was in the current decade, when $23 \%$ of all the herbarium sheets were created as a part of several comprehensive field surveys of macrophytes across Croatia, conducted by the project team of Professor Antun Alegro. A similar pattern was found among invasive plant taxa in ZA, the average age of which is 83 years (Vilović et al., 2020). By contrast, the average age of specimens in the orchid collection from the same herbarium is much higher (113 years), as a result of the sta- 


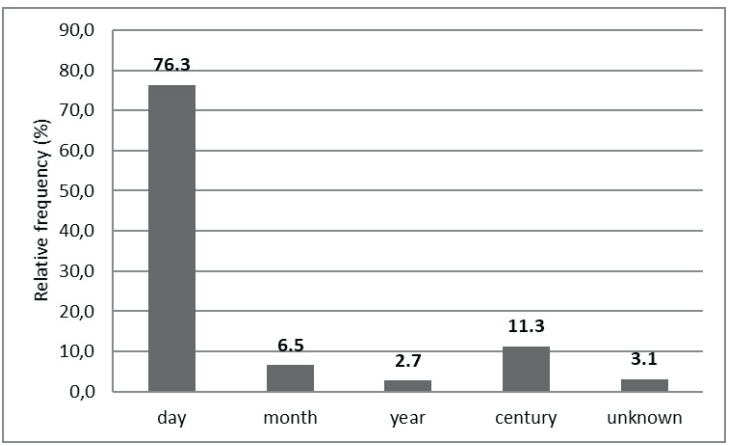

Fig. 4. The temporal precision of the dating of analysed material

tutory protection of orchids that reduced collecting activity and led to the increased use of modern colour photography instead (ŠEGOTA et al., 2019c). Globally, collecting activity was very weak in the second half of the last century, most probably due to reduced interest in plant taxonomy and the change in the attitude to plant collecting, considered to be an old-fashioned discipline (Wortley et al., 2002; Prather et al., 2004; Crawford et al., 2009; Molnár et al., 2012). Moreover, in the ZA collection, the arbitrarily proclaimed spatial limitations of the collection, the policy of rejecting insertions of new plant material and the lack of custodians in some periods discouraged botanists from collecting plant material and from depositing it in the herbarium.

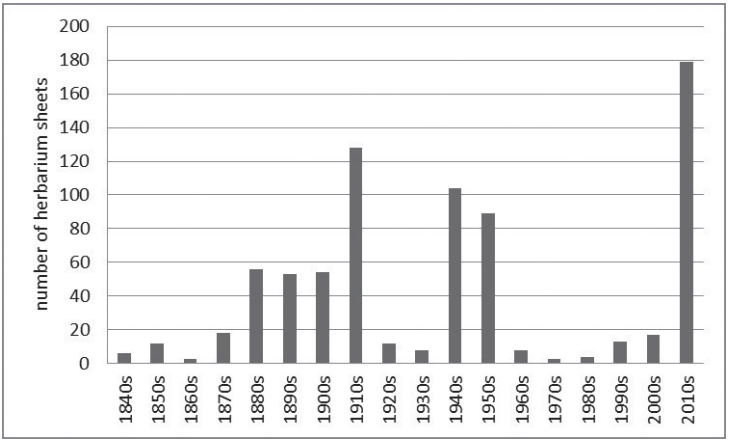

Fig. 5. The numbers of herbarium sheets collected in different decades

With regard to the geographic coverage of the collection, it is evident that collected aquatic plants are highly concentrated in Croatia (84\%) (Fig. 6, Tab. 1). This was expected, since we studied only the core part of the collection (Herbarium Croaticum sensu stricto), which keeps plant material collected in the Croatian territory and only to some extent from neighbouring countries. The same was observed during studies of the the collections of orchids (ŠGota et al., 2019c) and invasive flora (VILović et al., 2020) in ZA. We found specimens collected in eight additional countries: Slovenia, Bosnia \& Herzegovina, Serbia, Montenegro, Austria, Northern Macedonia and Hungary, while 78 sheets are completely deficient in geographical data.

When the distribution map was overlapped with the network of larger watercourses, it became evident that some rivers were left without any data concerning their aquatic flora. The largest gaps are visible in the regions of Moslavina and western 
Slavonia (the Česma, Sunja, Ilova, Pakra, Bosut, Vuka, Karašica and other rivers), the region of Istria (Raša River), Lika (Lika River) and Dalmatia (the Čikola, Cetina, Suvaja and Matica rivers).

Tab. 1. Origin of collected aquatic plants

\begin{tabular}{|l|l|}
\hline country & No \\
\hline Croatia & 810 \\
\hline Slovenia & 45 \\
\hline Bosnia-Herzegovina & 11 \\
\hline Serbia & 8 \\
\hline Montenegro & 4 \\
\hline Austria & 3 \\
\hline Northern Macedonia & 3 \\
\hline Hungary & 1 \\
\hline unknown & 78 \\
\hline
\end{tabular}

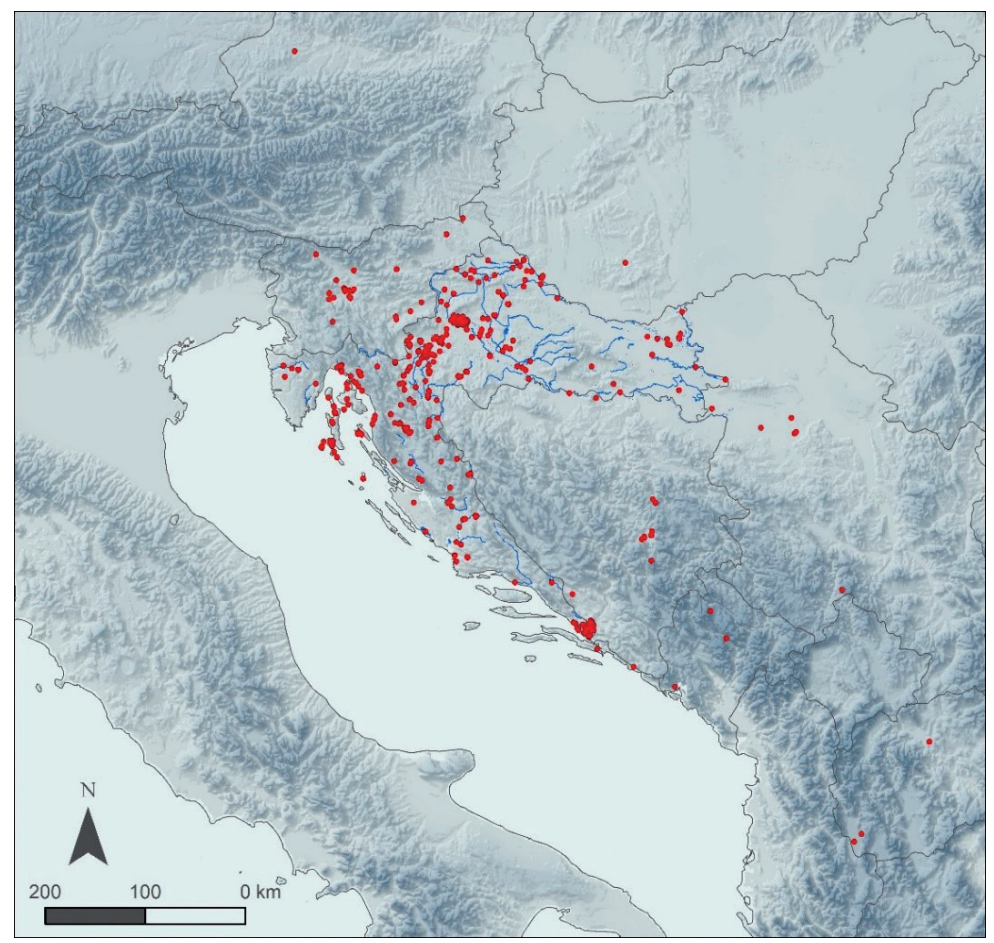

Fig. 6. The distribution map of aquatic plants based on ZA herbaria

The most prolific collectors of the aquatic plants in ZA were Ljudevit Rossi and J. K. Schlosser, contributing more than 100 sheets each, collected in the second half of the $19^{\text {th }}$ and the first two decades of the $20^{\text {th }}$ century. Out of a total 72 collectors, only five others collected more than 50 sheets: R. Domac, A. Alegro, Dragutin Hirc, Vedran Šegota and Lj. Marković (Tab. 2). The majority of collectors (55) contributed fewer than 10 sheets each, indicating that their activities were just casual. Only 13 sheets lack any information about the collector. Several contributors collected their material only from Slovenia (e.g. A. Paulin) or Bosnia \& Herzegovina (e.g. Karl Maly).

The collection keeps several extremely rare aquatic taxa; herbarium exsiccates are the only evidence of the former existence of some of them in the Croatian flora. A particularly striking example is the regionally extinct species Caldesia parnassifolia collected by J. K. Schlosser in Lonjsko polje, without an exact collection date, never found again in Cro- 


\begin{tabular}{|l|c|c|c|}
\hline Collector & No. of specimens & No. of taxa & Time period \\
\hline Rossi, Lj. (1850-1932) & 133 & 33 & $1868-1926$ \\
\hline Schlosser, K. (1808-1882) & 103 & 59 & $1844-1856$ \\
\hline Domac, R. (1918-2003) & 83 & 12 & 1949 \\
\hline Alegro, A. (et al.) (1974-) & 77 & 8 & $2016-2017$ \\
\hline Hirc, D. (1853-1921) & 77 & 29 & $1881-1914$ \\
\hline Šegota, V. (et al.) (1982-) & 69 & 25 & $2004-2018$ \\
\hline Marković (Gospodarić), Lj. (1932-) & 63 & 29 & $1951-1997$ \\
\hline Paulin, A. (1853-1942) & 40 & 32 & unknown \\
\hline Gjurašin, S. (1867-1936) & 31 & 24 & $1887-1923$ \\
\hline Haračić, A. (1855-1916) & 24 & 6 & $1889-1914$ \\
\hline Uđbinac (Štefanac), Z. (1934-2019) & 23 & 15 & $1953-1958$ \\
\hline Vuković, N. (et al.) (1980-) & 21 & 10 & $2002-2018$ \\
\hline Vukotinović, Lj. (1813-1893) & 18 & 15 & $1852-1882$ \\
\hline Klinggräff, H. (1820-1902) & 15 & 14 & unknown \\
\hline Loschnigg, V. (1897-?) & 11 & 9 & $1929-1942$ \\
\hline
\end{tabular}

Tab. 2. The fifteen most productive collectors of aquatic flora in ZA collection

atia. Another interesting case is a herbarium sheet of Luronium natans collected by Lj. Rossi in 1916 in the Korana River near Karlovac. This is the only historical proof of the existence of this species in Croatia, although, no plant material exists on the sheet. Only the label with collection data is present while the material was probably either lost in the various relocations of the herbarium, or by degradation by insects or fungal attack as no suitable preventive measures were taken in the past.

Herbarium specimens are often crucial for providing insight into the distribution of some data-deficient aquatic taxa in Croatia. The best example is the taxonomically very challenging genus Callitriche. Three taxa of this genus are known for the Croatian flora only from herbarium exsiccates: Callitriche platycarpa (two sheets collected by Zlata Uđbinac in Crna Mlaka in the mid-20 $0^{\text {th }}$ century and one sheet by J. K. Schlosser in Lonjsko polje, date unknown), C. truncata (two sheets from the island of Krk collected by M. G. S. Tommasini in the second part of the $19^{\text {th }}$ century) and C. hermaphroditica (one sheet collected in Topusko in 1908 by D. Hirc and two sheets by J. K. Schlosser in Moslavina without a known date).

Schlosser's collection of Potamogeton species from $19^{\text {th }}$ century revealed three datadeficient species, with no subsequent records in Croatian flora. Those are Potamogeton alpinus from Lonjsko polje, $P$. compressus from Lonja River and P. polygonifolius without the exact locality noted. Schlosser also collected one specimen of Sparganium minimum, in Podravina in 1846, which remained the only record of this species in Croatia. The same holds for one herbarium sheet of the rare and probably under-recorded hybrid species Nuphar $\times$ spenneriana collected in Divoselo in 1881 by Vincze von Borbás.

The collection is also a valuable source of distributional data for several critically endangered (Hydrocotyle vulgaris, Baldellia ranunculoides) and endangered (Hippuris vulgaris, Lemna gibba, Marsilea quadrifolia, Menyanthes trifoliata, Ranunculus lingua, R. ophioglossifolius) taxa of Croatian flora (Nikolić \& Topić, 2005). In addition, we found two herbarium specimens of the rare NATURA 2000 species Apium repens collected in the Zrmanja River by J. K. Schlosser in the $19^{\text {th }}$ century. This herbarium material is the only historical proof of its existence in Dalmatia, indicating a larger extent of occurrence in the past followed by the reduction of its population size. 
Furthermore, several studies have shown the significant usefulness of herbarium records in plant invasion studies (PYŠEK \& PRACH, 1993; MinulKa \& PYšEK, 2001; Mandák et al., 2004; Wu et al., 2004; FuENTEs et al., 2008), as herbarium specimens are often the first evidence of invasion starting points in a particular area. In our collection, this is shown in the case of the aquatic alien Elodea canadensis. Although the species was first mentioned in the literature in 1954, the herbarium specimens collected by Schlosser in $19^{\text {th }}$ century in Sisak indicate that this invasive aquatic alien was present in Croatia at least 60 years before notice of its arrival was published.

Aquatic plants are probably the most threatened plant species in Croatia, due to the numerous negative impacts on their natural habitats, such as river canalisation, waterbed deepening, eutrophication and pollution. This study is a good starting point for future field studies, which should focus on clarifying their recent distribution, track historical changes of their populations, and raise the awareness of the need for the protection of fragile aquatic habitats in Croatia.

Received March 16, 2020

\section{REFERENCES}

Alegro, A., Stanković, I., Šegota, V., van de Wayer \& Blaženčić, J., 2016: Macrophytic vegetation in the oligotrophic Mediterranean lake Vrana (Island of Cres, Northern Adriatic) - New insight after 50 years. Botanica Serbica, (40)1, 21-28.

Alegro, A., Šegota, V., Rimac, A., Kiebacher, T., Prlić, D., Sedlar, Z., Vuković, N. \& Papp, B., 2019: New and noteworthy bryophyte records from Croatia. Cryptogamie Bryologie 40(1), 5-13.

Butcher, R. W., 1927: A preliminary account of the vegetation of the River Itchen. Journal of Ecology 15, $55-65$.

Chen, Y., Jabbour, F., Novikov, A., Wang, W. \& Gerber, S., 2018: A study of floral shape variation in Delphinieae (Ranunculaceae) using geometric morphometrics on herbarium specimens. Botany Letters 165(3-4), 368-376.

Crawford, P. H. C. \& Hoagland, B. W., 2009: Can herbarium records be used to map alien species invasion and native species expansion over the past 100 years? Journal of Biogeography 36, 651-661.

Damerval, C., Othman, W. B., Manicacci, D. \& Jabbour, F., 2018: Distribution area of the two floral morphs of Nigella damascene L. (Ranunculaceae): a diachronic study using herbarium specimens collected in France. Botany Letters 165(3-4), 396-403.

European Community, 2000: Directive 2000/60/EC of the European Parliament and of the Council of 23 October 2000 establishing a framework for Community action in the field of water policy. On-Line (http://eur-lex.europa.eu), accessed on 2 March 2020.

Fuentes, N., Ugarte, E., KüHn, I. \& Klotz, S., 2008: Alien plants in Chile: inferring invasion periods from herbarium records. Biological Invasions 10, 649-657.

Gessner, F., 1955: Hydrobotanik I. Energiehaushalt. Hochschulbücher für Biologie 3. Berlin.

Koletić, N., Alegro, A., Rimac, A., Vuković, N. \& Šmgota, V., 2020: Catalogue of Croatian freshwater rhodophytes. Phytotaxa 434(2), 151-169.

Koletić, N., Alegro, A., Šegota, V., Vuković, N., Rimac, A. \& Vilović, T., 2017: New sites of rare cold-water golden algae Hydrurus foetidus (Villars) Trevisan (Ochrophyta: Chrysophyceae) in Croatia. Natura Croatica 26(2), 305-311.

Koletić, N., Alegro, A., Vuković, N., Rimac, A. \& Šegota, V., 2018: Spotting the spots: The freshwater brown alga Heribaudiella fluviatilis (Areschoug) Svedelius within stream communities of Southeastern Europe. Cryptogamie Algologie 39(4), 449-463.

Koletić, N., Rimac, A., Alegro, A., Lajtner, J., Vuković, N. \& Šegota, V., 2019: Dynamics of epizoic populations of Thorea hispida (Thore) Desvaux (Thoreaceae, Rhodophyta) on aquatic gastropods in the carbonate stream in Croatia. Nowa Hedwigia 109(1-2), 1-15.

Lang, P. L. M., Willems, F. M., Scheepens, J. F., Burbano, H. A. \& Bossdorf, O., 2019: Using herbaria to study global environmental change. New Phytologist 221(1), 110-122. 
Lister, A. M., 2011: Natural History Collections as Sources of Long-Term Datasets. Trend sin Ecology and Evolution 26, 153-154.

Lukács, B. A., Mesterházy, A., VidéKi, R. \& Király, G., 2016: Alien aquatic vascular plants in Hungary (Pannonian ecoregion): Histroical aspects, dana set and trends. Plant Biosystems 150(3), 388-395.

Mandék, B., PyšEK, P. \& Kateřına, B., 2004: History of the invasion and distribution of Reynoutria taxa in the Czech Republic: a hybrid spreading faster than its parents. Preslia 76, 15-64.

MinulKa, S. \& PYšEK, P., 2001: Invasion history of Oenothera congeners in Europe: a comparative study of spreading rates in the last 200 years. Journal of Biogeography 28, 597-609.

Molnár, A.V., Takács, A., Horváth, O., Vojtkó, A.E., Király, G., Sonkoly, J., Sulyok, J. \& Sramkó, G., 2012: Herbarium Database of Hungarian Orchids I. Methodology, dataset, historical aspects and taxa. Biologia 67(1), 79-86.

Nikolıć, T. \& Topıć, J., 2005: Crvena knjiga vaskularne flore Hrvatske. Ministatsvo kulture, Državni zavod za zaštitu prirode, Zagreb.

Nikolić, T. (ED.), 2020: Flora Croatica Database. On-Line (http://hirc.botanic.hr/fcd). Division of Botany, Faculty of Science, University of Zagreb, accessed on 1 January 2020.

Popiela, A., Łysko, A., Molnár, A. V., KĄCKI, Z. \& Lukácz, B. A., 2015: Distribution, morphology and habitat of Elatine triandra (Elatinaceae) in Europe, with particular reference to the central part of the continent. Acta Botanica Gallica: Botany Letters 162, 325-337.

Prather, L. A., Alvarez-Fuentes, O., Mayfield, M. H. \& Ferguson, C. J., 2004: The decline of plant collecting in the United States: a threat to the infrastructure of biodiversity studies. Systematic Botany 29, 15-28.

PYŠEK, P. \& PrACH, K., 1993: Plant invasion and the role of riparian habitats: a comparison of four species alien to central Europe. Journal of Biogeography 20, 413-420.

ReŠETnIK, I. \& ŠEgotA, V., 2020: Virtual herbarium ZA \& ZAHO. On-line (http://herbariumcroaticum.biol. pmf.hr). Division of Botany, Faculty of Science, University of Zagreb, accessed on 1 January 2020.

Rimac, A., Stanković, I., Alegro, A., Gottstein, S., Koletić, N., Vuković, N., Šegota, V. \& Žižić-Nakić, A., 2018: The Brazilian Elodea (Egeria densa Planch.) invasion reaches Southeast Europe. Bioinvasions Records 7(4), 381-389.

Rimac, A., Šegota, V., Alegro, A., Koletić, N., Vuković, N. \& PApp B., 2019: New and noteworthy bryophyte records from lacustrine drawdown zones in Croatia. Herzogia 32(2), 315.

Soltis, P. S., 2017: Digitization of Herbaria Enables Novel Research. American Journal of Botany 104, 1-4.

Šegota, V., Gulin, I., Rimac, A. \& Alegro, A., 2019a: Contribution to bryophyte flora of Croatia: new finding of rare aquatic moss Fissidens fontanus (Bach. Pyl.) Steud. in Lake Visovac (Krka National Park). Natura Croatica 28(1), 63-71.

Šmgota, V., Zlatković, B., Vukov, D., Alegro, A., Koletić, N., Vuković, N. \& Rimac, A., 2019b: Status assessment of the rare aquatic plant Groenlandia densa (L.) Fourr. (Potamogetonaceae) in the Western Balkans. Botany Letters 166, 125-133.

Šegota, V., Vilović, T. \& Zovко, I., 2019c: Orchid (Orchidaceae) diversity within Herbarium Croaticum (ZA) collection sensu stricto. Natura Croatica 28(2), 325-343.

Takács, A., Molnár, A. V., Horváth, O., Sramkó, G., Popiela, A., Mesterházy, A., Lovas-Kiss, Á., Green, A. J., LöKI, V., NAgY, T., LukÁcz, B. A., 2017: The rare aquatic angiosperm Elatine gussonei (Elatinaceae) is more widely distributed than previously thought. Aquatic Botany 141, 47-50.

THIERs, B., 2020: Index Herbariorum. On-Line (http://sweetgum.nybg.org/ih/) A global directory of public herbaria and associated staff. New York Botanical Garden's Virtual Herbarium, accesses on 1 January 2020.

Vilović, T., ŠEgota, V., Bilić, K. \& Nikolić, T., 2020: Searching for invasive aliens: A case study from ZA \& ZAHO herbarium collections. Natura Croatica 29(1), 99-108.

WANG, W., 2018: A primer to the use of herbarium specimens in plant phylogenetics. Botany Letters 165(34), 404-408.

Wiegleb, G. \& Kaplan, Z., 1998: An account of the species of Potamogeton L. (Potamogetonaceae). Folia Geobotanica 33, 241-316.

Wortley, A. H., Benet, J. R. \& Scotland, R. W., 2002: Taxonomy and phylogeny reconstruction: two distinct research agenda in systematic. Edinburgh Journal of Botany 59, 335-349.

Wu, S. H., Hsieh, C. F., Chaw, S. M. \& Rejmánek, M., 2004: Plant invasions in Taiwan: insights from the flora of casual and naturalized alien species. Diversity and Distributions 10, 349-362. 
Appendix 1. Taxa list by alphabetical order

Alisma lanceolatum With.

Alisma plantago-aquatica L.

Apium repens (Jacq.) Lag.

Azolla filiculoides Lam.

Baldellia ranunculoides (L.) Parl.

Berula erecta (Huds.) Coville

Butomus umbellatus L.

Caldesia parnassifolia (L.) Parl.

Callitriche cophocarpa Sendtn.

Callitriche hermaphroditica L.

Callitriche platycarpa Kütz

Callitriche truncata Guss.

Ceratophyllum demersum L.

Ceratophyllum submersum L.

Damasonium polyspermum Cosson

Egeria densa Planch.

Elodea canadensis Michx.

Groenlandia densa (L.) Fourr.

Hippuris vulgaris L.

Hottonia palustris L.

Hydrocharis morsus-ranae L.

Hydrocotyle vulgaris L.

Lemna gibba L.

Lemna minor L.

Lemna trisulca L.

Luronium natans (L.) Rafin.

Marsilea quadrifolia $\mathrm{L}$.

Menyanthes trifoliata L.

Myriophyllum alterniflorum DC.

Myriophyllum spicatum L.

Myriophyllum verticillatum L.

Najas marina L.

Najas minor All.

Nuphar lutea Sibth. et Sm.

Nuphar x spenneriana Gaudin

Nymphaea alba L.

Nymphoides peltata (S. G. Gmelin) Kuntze

Polygonum amphibium L.

Potamogeton alpinus Balb.

Potamogeton berchtoldii Fieber

Potamogeton coloratus Hornem

Potamogeton compressus L.

Potamogeton crispus L.

Potamogeton gramineus L.

Potamogeton lucens L.

Potamogeton natans L.

Potamogeton nodosus L. 
Potamogeton pectinatus L.

Potamogeton perfoliatus L.

Potamogeton polygonifolius Pourr.

Potamogeton pusillus L.

Potamogeton trichoides Cham. et Schltell.

Ranunculus aquatilis L.

Ranunculus circinatus Sibth.

Ranunculus fluitans Lam.

Ranunculus lingua L.

Ranunculus ophioglossifolius Vill.

Ranunculus peltatus Schrank

Ranunculus trichophyllus Chaix in Vill.

Sagittaria sagittifolia L.

Salvinia natans (L.) All.

Sparganium emersum Rehmann

Sparganium erectum L.

Sparganium erectum L. ssp. neglectum (Beeby) Schinz et Thell.

Sparganium minimum Wallr.

Spirodela polyrhiza (L.) Schleiden

Stratiotes aloides L.

Trapa natans L.

Utricularia australis R. Br.

Utricularia minor $\mathrm{L}$.

Utricularia vulgaris L.

Vallisneria spiralis L.

Wolffia arrhiza (L.) Horkel et Wimm.

Zannichellia palustris L. 